\title{
Cloning, mapping and conjugal mobility of pLPG36, a common plasmid from Legionella pneumophila serogroup-1
}

\author{
F. LÓPEZ DE FELIPE* \\ Servicio de Bacteriologia, Centro Nacional de Microbiología, Madrid, Spain
}

(Received 16 December 1992; revised 19 July 1993; accepted 12 August 1993)

\begin{abstract}
A plasmid designated pLPG36 was isolated from the naturally occurring Legionella pneumophila serogroup-1 and purified by $\mathrm{CsCl}$ buoyant density centrifugation. A restriction map of this $58 \mathrm{~kb}$ plasmid was constructed and provided the basis for cloning four BamHI fragments into the unique BamHI site of pUC18. The four recombinant plasmids were investigated for the mobilization function in Escherichia coli strains. Only one of these, pFLJ2, was mobilized by the IncP plasmids RP4, pRK231 and R702, but not by plasmids pSa, R40a, R387, pN3 or R16. The derivative plasmid pFLJ2 was mobilized more efficiently by R702 than by RP4 or pRK231. By genetic and deletion analysis, the mobilization region of pLPG36 was located to a $6 \mathrm{~kb} E c o$ RI fragment of the plasmid.
\end{abstract}

\section{Introduction}

At the present time, a genetic system suitable for the study of the structure and expression of Legionella pneumophila genes in both native and heterologous hosts is not available.

The genetic manipulation of bacteria depends to a large extent on plasmids. However, no plasmid, whether large or small, of $L$. pneumophila has been isolated and characterized to date. Thus, recombinant DNA techniques cannot be used in this organism.

The importance of mobilization functions in promoting genetic exchange in bacterial systems, prompted us to study the transfer of Legionella plasmids. The oriT function would be an excellent tool to effect direct Legionella-Legionella or Legionella to heterologous host gene transfers.

Recently, two groups (Mintz et al., 1992; Tully, 1991) have identified self-transmissible plasmids in L. pneumophila serogroup-1. The presence of such self-transmissible plasmids in the same donor cell is required for mobilization of non-conjugative plasmids during mating (Guiney \& Yakobson, 1983).

Previously, we have screened 78 selected clinical and environmental Spanish strains of L. pneumophila serogroup-1 for the presence of plasmids. A widely distributed plasmid of $36 \mathrm{MDa}$, called pLPG36, was chosen for

* Present address: Centro de Investigaciones Biológicas, CSIC, Velázquez 144, 28006 Madrid, Spain. Tel. + 341 5611800; fax +3415627518. further molecular studies (López de Felipe \& MartinezSuárez, 1991). The presence of pLPG36 in a high proportion of environmental and clinical isolates of $L$. pneumophila serogroup-1, along with the co-existence of this plasmid in some strains also containing a cryptic plasmid of $80 \mathrm{MDa}$ (López de Felipe \& MartinezSuárez, 1991), suggested that pLPG36 might be mobilizable.

In this study, we present the first description of the isolation, cloning and mapping of a Legionella plasmid and also the localization of the mobilization region to a $6 \mathrm{~kb}$ EcoRI fragment.

\section{Methods}

Bacterial strains and plasmids. Bacterial strains and plasmids used in this work are listed in Table 1.

Media and growth conditions. Escherichia coli strains were grown with shaking in L-broth or on L-agar plates at $37^{\circ} \mathrm{C}$. Where appropriate, the medium was supplemented with the following antibiotics: ampicillin $\left(50 \mu \mathrm{g} \mathrm{ml}^{-1}\right)$; kanamycin $\left(25 \mu \mathrm{g} \mathrm{ml}^{-1}\right)$; chloramphenicol $\left(20 \mu \mathrm{g} \mathrm{ml}^{-1}\right)$; nalidixic acid $\left(50 \mu \mathrm{g} \mathrm{ml}^{-1}\right)$; rifampicin $\left(200 \mu \mathrm{g} \mathrm{ml}^{-1}\right)$; tetracycline $\left(10 \mu \mathrm{g} \mathrm{ml}^{-1}\right)$; or a combination of these antibiotics. X-gal and IPTG were used at $40 \mu \mathrm{g} \mathrm{ml}^{-1}$ and $0 \cdot 12 \mu \mathrm{g} \mathrm{ml}^{-1}$, respectively. L. pneumophila serogroup- 1 strain 53048 was grown in Buffered Charcoal Yeast Extract (BCYE- $\alpha$ ) plates (Edelstein, 1981) at $37^{\circ} \mathrm{C}$ in a humid atmosphere. For large-scale pLPG36 plasmid isolation, L. pneumophila was grown as described previously (López de Felipe \& Martinez-Suárez, 1991).

Isolation and purification of pLPG36. Large-scale isolation of pLPG36 plasmid DNA from L. pneumophila was performed by the method of Rosenberg et al. (1982) with the following modifications: bacterial cells were harvested by centrifugation $(3000 \mathrm{~g})$ from 1 litre of 
Table 1. Bacterial strains and plasmids

\begin{tabular}{|c|c|c|}
\hline Strain or plasmid & Relevant characteristics* & Reference/source \\
\hline E. coli $\mathrm{HB} 101$ & $\operatorname{rec} A \mathrm{r}^{-} \mathrm{m}^{-}$ & Maniatis et al. (1982) \\
\hline E. coli $\mathrm{HB} 101 \mathrm{NxRf}$ & $\operatorname{rec} A \mathrm{r}^{-} \mathrm{m}^{-}, \mathrm{Nx}^{\mathrm{R}} \mathrm{Rf}^{\mathrm{R}}$ & This study \\
\hline L. pneumophila 53048 & Environmental serogroup-1 isolate & CNMVIS collection $\dagger$ \\
\hline pUC18 & $\mathrm{Ap}^{\mathrm{R}} l a c Z$ & Vieira \& Messing (1982) \\
\hline pSU2718 & $\mathrm{Cm}^{\mathrm{R}}$ lac $Z$ & Martinez et al. (1988) \\
\hline R702 & $\mathrm{Km}^{\mathrm{R}} \mathrm{Sm}^{\mathrm{R}} \mathrm{Su}^{\mathrm{R}} \mathrm{Tc}^{\mathrm{R}} \operatorname{IncP}$ & (Shapiro, 1977) \\
\hline RP4 & $\mathrm{Ap}^{\mathrm{R}} \mathrm{Km}^{\mathrm{R}} \mathrm{Nm}^{\mathrm{R}} \mathrm{Tc}^{\mathrm{R}} \mathrm{IncP}$ & (Shapiro, 1977) \\
\hline pRK231 & $\mathrm{Km}^{\mathrm{R}} \mathrm{Nm}^{\mathrm{R}} \mathrm{Tc}^{\mathrm{R}}$ IncP & (Guiney \& Yakobson, 1983) \\
\hline $\mathrm{pN} 3$ & $\mathrm{Sm}^{\mathrm{R}} \mathrm{Tc}^{\mathrm{R}} \mathrm{Su}^{\mathrm{R}} \mathrm{IncN}$ & (Shapiro, 1977) \\
\hline $\mathrm{R} 16$ & $A p^{R} S^{R} T^{R}{ }^{R} u^{R} \operatorname{IncB}$ & (Shapiro, 1977) \\
\hline $\mathrm{R} 40 \mathrm{a}$ & $\mathrm{Ap}^{\mathrm{R}} \mathrm{Km}^{\mathrm{R}} \mathrm{Su}^{\mathrm{R}}$ IncC & (Shapiro, 1977) \\
\hline $\mathrm{pSa}$ & $\mathrm{Cm}^{\mathrm{R}} \mathrm{Km}^{\mathrm{R}} \mathrm{Sm}^{\mathrm{R}} \mathrm{Su}^{\mathrm{R}} \mathrm{IncW}$ & (Shapiro, 1977) \\
\hline R387 & $\mathrm{Cm}^{\mathrm{R}} \mathrm{Sm}^{\mathrm{R}} \mathrm{IncK}$ & (Shapiro, 1977) \\
\hline pLPG36 & $m o b$ & This study \\
\hline pFLJ1 & $\begin{array}{l}25.7 \mathrm{~kb} \text { BamHI fragment of pLPG36 } \\
\text { in pUC18. Ap }\end{array}$ & This study \\
\hline $\mathrm{pFLJ} 2$ & $\begin{array}{l}16.4 \mathrm{~kb} \text { Bam } \mathrm{HI} \text { fragment of pLPG } 36 \\
\text { in pUC18. Ap }{ }^{\mathrm{R}} \text { mob }\end{array}$ & This study \\
\hline pFLJ3 & $\begin{array}{l}10.9 \mathrm{~kb} \text { BamHI fragment of pLPG } 36 \\
\text { in pUC18. Ap }\end{array}$ & This study \\
\hline $\mathrm{pFLJ4}$ & $\begin{array}{l}5 \mathrm{~kb} \text { Bam HI fragment of pLPG36 in } \\
\text { pUC18. Ap }\end{array}$ & This study \\
\hline $\mathrm{pFLJ} 21$ & $\begin{array}{l}9 \mathrm{~kb} E c o \text { RI fragment of } \mathrm{pFLJ} 2 \text { in } \\
\mathrm{pUC} 18 . \mathrm{Ap}^{\mathrm{R}}\end{array}$ & This study \\
\hline pFLJ22 & $\begin{array}{l}6 \mathrm{~kb} E c o \mathrm{RI} \text { fragment of } \mathrm{pFLJ} 2 \text { in } \\
\text { pUC18. Ap }{ }^{\mathrm{R}} m o b\end{array}$ & This study \\
\hline
\end{tabular}

*Abbreviations: Ap, ampicillin; $\mathrm{Cm}$, chloramphenicol; $\mathrm{Km}$, kanamycin; $\mathrm{Nm}$, neomycin; $\mathrm{Sm}$, streptomycin; Su, sulfonamide; Tc, tetracycline; $\mathrm{Nx}$, nalidixic acid; Rf, rifampicin; mob, mobilization proficient; $\operatorname{rec} A$, recombination deficient $; \mathrm{r}^{-} \mathrm{m}^{-}$, restriction deficient and modification deficient.

$\dagger$ Centro Nacional de Microbiología, Madrid, Spain.

an overnight culture in Yeast Extract Broth (YEB), and the bacterial pellet was resuspended in $150 \mathrm{ml} 1 \mathrm{M}-\mathrm{NaCl}$ and washed for $30 \mathrm{~min}$ at $28^{\circ} \mathrm{C}$. The cells were then washed twice in TES pH 8.0 (50 mm-Tris, $5 \mathrm{~mm}$-EDTA, $10 \mathrm{~mm}-\mathrm{NaCl}$ ) at room temperature. The cell pellet was finally resuspended in $25 \mathrm{ml}$ of a fresh lysozyme solution $\left(5 \mathrm{mg} \mathrm{ml}^{-1}\right.$ in TE, $\mathrm{pH} 8.0$ ) and incubated for $30 \mathrm{~min}$ at $37^{\circ} \mathrm{C}$. After addition of $250 \mathrm{ml}$ lysis buffer [1\%, w/v, SDS in TE, pH 12.45 (with $10 \mathrm{M}-\mathrm{NaOH}$ )], the suspension was gently mixed for $30 \mathrm{~min}$ at $37^{\circ} \mathrm{C}$ and then the $\mathrm{pH}$ was adjusted to $\mathrm{pH} 8.3$ with $2 \mathrm{M}$-Tris/ $\mathrm{HCl}, \mathrm{pH} 7 \cdot 0 . \mathrm{NaCl}$ was added to a final concentration of $1 \mathrm{~m}$ and the mixture incubated for $6 \mathrm{~h}$ on ice. After centrifugation at $10000 \mathrm{~g}$ for $30 \mathrm{~min}$, PEG 6000 was added to the supernatant to a final concentration of $10 \%(\mathrm{w} / \mathrm{v})$. The mixture was incubated overnight at $4{ }^{\circ} \mathrm{C}$ for the precipitation of plasmid DNA which was then pelleted by centrifugation at $10000 \mathrm{~g}$ for $30 \mathrm{~min}$. The final pellet was resuspended in $10 \mathrm{ml} \mathrm{TE}$ and divided into portions of $3.6 \mathrm{ml}$ to which $3.6 \mathrm{~g} \mathrm{CsCl}$ and $100 \mu \mathrm{l}$ of ethidium bromide $\left(10 \mathrm{mg} \mathrm{ml}^{-1}\right)$ were added. The tubes were centrifuged in a V65Ti vertical rotor (DuPont) for $8 \mathrm{~h}$ at 45000 r.p.m. The plasmid DNA was collected and extracted with isopropanol-chloroform before dialysis against $10 \mathrm{~mm}$ Tris, $\mathrm{pH} 8.0$.

DNA manipulation. Cloning procedures were as described by Maniatis et al. (1982). Restriction enzymes and T4 DNA ligase were purchased from Pharmacia and used according to the manufacturer's instructions. $E$. coli cells were made competent and transformed by the method of Hanahan (1983). The four BamHI fragments used for cloning pLPG36 DNA into pUC18 were separated in $0.7 \%$ agarose gels and the bands were recovered and purified using a GeneClean kit (Bio 101)
Conjugational DNA transfer and mobilization. Appropriate donor $\left(5 \times 10^{7}\right.$ cells $)$ and recipient cells $\left(10^{8}\right.$ cells $)$ were mixed and filtered through a Millipore filter $(0.45 \mu \mathrm{m}$ pore size, $25 \mathrm{~mm}$ diameter $)$. The filter was incubated for $6 \mathrm{~h}$ at $37^{\circ} \mathrm{C}$ on a LB plate without selection. The bacterial cells were resuspended and plated on selective L-agar plates containing the appropriate antibiotics. Transconjugants containing pUC18-pLPG36 recombinant plasmids (Table 1) were selected on L-agar plates containing ampicillin and rifampicin, whereas transfer of the mobilizing plasmid was detected by selection on plates containing rifampicin and the antibiotic marker of the helper plasmid. The putative transconjugants were checked for growth on L-agar containing nalidixic acid to ensure that they were true transconjugants rather than rifampicin-resistant spontaneous mutants of the donor.

\section{Results}

\section{Isolation and purification of pLPG36}

Although pLPG36 is not a large plasmid, we chose a method of gentle lysis for purification of the DNA of large plasmids from Gram-negative bacteria (Rosenberg et al., 1982) to prevent degradation or loss of plasmid DNA. Several modifications were made, including neutralization, the addition of salts and overnight PEG precipitation, to improve the quality and yield of plasmid DNA (data not shown). The modified preparative 
method yielded $173 \mu \mathrm{g}$ of purified plasmid DNA from 1 litre of stationary-phase culture.

\section{Physical mapping of pLPG36}

Purified pLPG36 plasmid DNA was mapped with SmaI, SalI, XhoI, SacI and BamHI. Single and double digests of pLPG36 with these five enzymes resulted in the fragments shown in Table 2 . These fragments could only be arranged as shown in the circular physical map in Fig. 1. Moreover, cleavage of the four cloned BamHI fragments with the above endonucleases confirmed the restriction fragment sizes obtained with purified pLPG36 DNA. The EcoRI sites were mapped on cloned BamHI fragments B $(16.4 \mathrm{~kb}), \mathrm{C}(10.9 \mathrm{~kb})$ and $\mathrm{D}(5.0 \mathrm{~kb})$. The precise location of five $E c o$ RI sites of the $25.7 \mathrm{~kb} B a m \mathrm{HI}-$ A fragment (coordinates 22.2 to $42.7 \mathrm{~kb}$ ) is not known.

\section{Cloning of pLPG36 DNA}

The purified BamHI fragments of pLPG36 $(25 \cdot 7,16 \cdot 4$, 10.9 and $5 \mathrm{~kb}$ ) were cloned initially into the unique BamHI site of the intermediate copy number plasmid vector, pSU2718 (Martinez et al., 1988). The fragments were then transferred to the high copy number plasmid vector, pUC18 (Vieira \& Messing, 1982) to give the four recombinant plasmids denoted pFLJ1, pFLJ2, pFLJ3 and $\mathrm{pFLJ} 4$, respectively, to investigate their mobilization potential.

\section{Localization of mobilization region in recombinant plasmids derived from $p L P G 36$}

To show that pLPG36 contained an origin of transfer functional in vivo, mobilization experiments were carried out on recombinant plasmids. For the conjugative mobilization of the pLPG36 derivatives, donor strains were made by transforming each of the test plasmids into E. coli HB101 containing R702, RP4, pRK231, pN3, $\mathrm{R} 16, \mathrm{R} 40 \mathrm{a}$, pSa or R387 as the mobilizing plasmid. For the conjugative mobilization of the pFLJ2 derivatives, the donor strains were made by transforming each of the test plasmids into $\mathrm{HB} 101$ containing $\mathrm{R} 702$ as the mobilizing plasmid. The recipient was a rifampicin- and nalidixic acid-resistant derivative of HB101. All the recombinant plasmids were unable to transfer among the E. coli strains (transfer frequencies $<1 \times 10^{-8}$ ). To rule out mobilization as the result of homologous recombination between the mobilized and helper plasmid, a
Table 2. Single and double digests of pLPG36 with SmaI, SalI, XhoI, SacI and BamHI

\begin{tabular}{ll}
\hline \hline $\begin{array}{l}\text { Restriction } \\
\text { endonuclease }\end{array}$ & \multicolumn{1}{c}{ Fragment size $(\mathrm{kb})$} \\
\hline SmaI & $58 \cdot 0$ \\
SalI & $52 \cdot 5,5 \cdot 5$ \\
XhoI & $46 \cdot 7,11 \cdot 3$ \\
SacI & $43 \cdot 1,8 \cdot 4,6 \cdot 5$ \\
BamHI & $25 \cdot 7,16 \cdot 4,10 \cdot 9,5 \cdot 0$ \\
SmaI-SalI & $28 \cdot 5,24 \cdot 0,5 \cdot 5$ \\
SmaI-XhoI & $45 \cdot 9,11 \cdot 3,0 \cdot 8$ \\
SmaI-SacI & $43 \cdot 1,6 \cdot 5,4 \cdot 8,3 \cdot 6$ \\
SmaI-Bam $\mathrm{HI}$ & $25 \cdot 7,16 \cdot 4,5 \cdot 8,5 \cdot 1,5 \cdot 0$ \\
SalI-XhoI & $24 \cdot 8,16 \cdot 4,11 \cdot 3,5 \cdot 5$ \\
SalI-SacI & $23 \cdot 7,13 \cdot 9,8 \cdot 4,6 \cdot 5,5 \cdot 5$ \\
SalI-BamHI & $18 \cdot 4,16 \cdot 4,10 \cdot 9,5 \cdot 5,5 \cdot 0,1 \cdot 8$ \\
XhoI-SacI & $35 \cdot 8,7 \cdot 3,6 \cdot 5,4 \cdot 4,4 \cdot 0$ \\
XhoI-BamHI & $23 \cdot 7,16 \cdot 4,6 \cdot 6,4 \cdot 3,5 \cdot 0,2 \cdot 0$ \\
SacI-BamHI & $25 \cdot 7,12 \cdot 1,8 \cdot 4,5 \cdot 0,4 \cdot 3,2 \cdot 2,0 \cdot 3$ \\
\hline
\end{tabular}

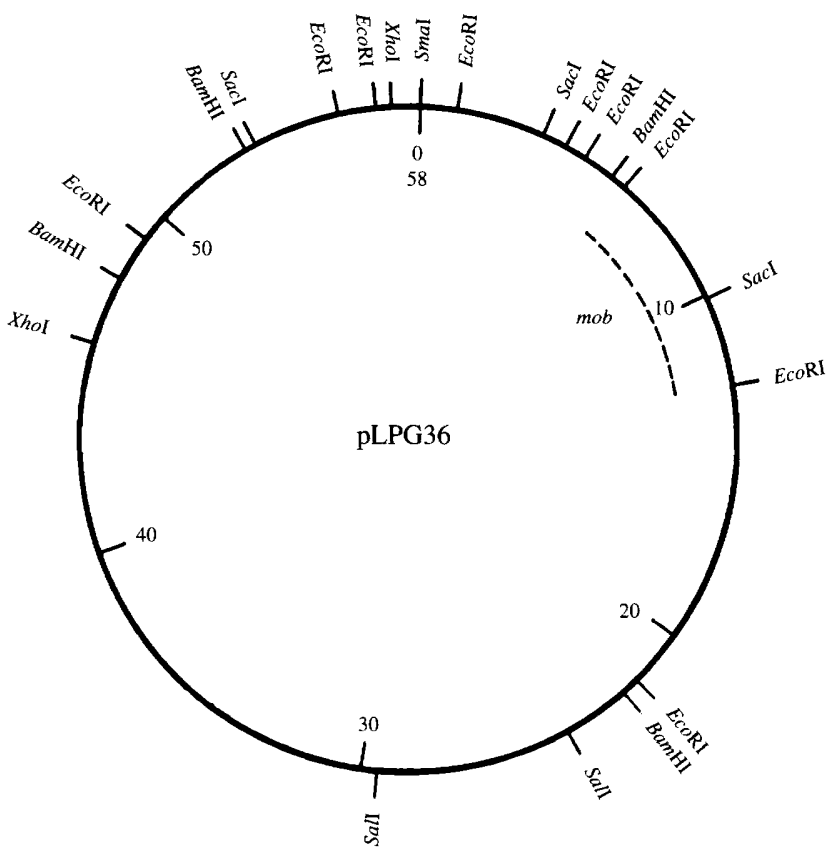

Fig. 1. Restriction map of pLPG36. Restriction sites have been orientated with respect to the single $S m a I$ site, and the distances $(\mathrm{kb})$ from this site are shown. The precise location of five EcoRI sites of the $25.7 \mathrm{~kb} \mathrm{BamHI}$-A fragment (coordinates 22.2 to $42.7 \mathrm{~kb}$ ) is not known.

recA E. coli strain was used. The broad host range IncP plasmid RP4 or the helper plasmid pRK231 did not mobilize pUC18, pFLJ1, pFLJ3 or pFLJ4, but mobilized the transfer of pFLJ2 at a frequency of $1 \cdot 1 \times 10^{-5}$ (Table 3). However, plasmid pFLJ2 was more efficiently transferred by the IncP plasmid R702, at a frequency of $2 \times 10^{-4}$ (Table 3 ).

Plasmids pSa (IncW), R40a (IncC), R387 (IncK), pN3 
Table 3. Mobilization of pLPG36 derivatives by the IncP $\propto$ plasmids $R P 4, p R K 231$ and $R 702$

\begin{tabular}{lcc}
\hline \hline Conjugative plasmid & Mobilized plasmid & Mobilization ratio* \\
\hline RP4 and pRK231 & pFLJ1 & $<1 \times 10^{-8}$ \\
& pFLJ2 & $1 \cdot 1 \times 10^{-5}$ \\
pFLJ3 & $<1 \times 10^{-8}$ \\
pFLJ4 & $<1 \times 10^{-8}$ \\
pUC18 & $<1 \times 10^{-8}$ \\
RF52 & pFL1 & $<1 \times 10^{-8}$ \\
& pFLJ2 & $2 \times 10^{-4}$ \\
& pFLJ4 & $<1 \times 10^{-8}$ \\
pUC18 & $<1 \times 10^{-8}$ \\
& pFLJ21 & $<1 \times 10^{-8}$ \\
& pFLJ22 & $2 \cdot 2 \times 10^{-4}$ \\
\hline \hline
\end{tabular}

* The mobilization ratio is the transfer frequency of the tested plasmid divided by the transfer frequency of the helper plasmid. Transfer frequencies are expressed as transconjugants per recipient cells. Ratios are the mean of three experiments.

(IncN) or R16 (IncB) did not mobilize any of the pLPG36 recombinant plasmids or pUC18 (transfer frequencies of $<1 \times 10^{-8}$ ).

\section{Subcloning of the mobilization region from $p F L J 2$}

The restriction map of pLPG36 provided the basis for the construction of the deletion plasmids pFLJ21 and pFLJ22 which contain the 9 and $6 \mathrm{~kb}$ Eco RI fragments of pFLJ2, respectively. For this purposes pFLJ2 was cut with $B a m \mathrm{HI}$ and EcoRI, religated and transformed into E. coli HB101 containing the helper plasmid R702.

The mobilization of these deletion plasmids by R702 was then determined. pFLJ22 was mobilized at similar frequencies to pFLJ2 $\left(2.2 \times 10^{-4}\right)$ whereas pFLJ21 was not mobilized by R702 (Table 3 ). These results showed that the $6 \mathrm{~kb} E c o$ RI fragment is sufficient for the mobilization of pLPG36, and that the mobilization region is located in this fragment.

\section{Discussion}

We have shown previously that the naturally occurring plasmid pLPG36 is widely distributed among clinical and environmental Spanish isolates of $L$. pneumophila serogroup 1 (López de Felipe \& Martinez-Suárez, 1991). To initiate the molecular analysis of pLPG36 we have isolated and purified it. The modified method used in this work to isolate and purify pLPG36 could be utilized for the isolation and purification of large plasmids which are frequently found in Legionella strains (Edelstein et al., 1986; Maher et al., 1987; Stout et al., 1988).

Construction of the pLPG36 physical map provided the basis for subcloning experiments and for location of the mobilization region to a $6 \mathrm{~kb} E c o$ RI fragment of the plasmid. Mobilization experiments with pLPG36 derivatives demonstrated that only one of these recombinant plasmids, pFLJ2, was mobilized by the IncP plasmid R702 at higher transfer frequencies than those using RP4 or pRK231 as mobilizing plasmids. Since plasmid oriT sequences are plasmid-specific and generally not functionally interchangeable (Willets \& Wilkins, 1984), the slight differences between transfer frequencies using helper plasmids of the same incompatibility group (IncP) may be the consequence of less efficient recognition of the pLPG36 mobilization region by the conjugation systems of RP4 or pRK231 than by those of R702.

The formation of co-integrates by rec $A$-independent transposition of insertion elements could be ruled out by the analysis of the plasmid DNA in the transconjugants (R702 and pFLJ2 or pFLJ22 were present in an unaltered form). It is of interest that the mobilization frequency of pLPG36 found in this study, is similar to the conjugation frequency of plasmid pCH1 (Mintz et al., 1992). This suggests that pLPG36 could be mobilized by pCH1 if both plasmids were in the same donor cell. In fact, we have found pLPG36 in serogroup-1 strains in which a cryptic plasmid also resides with an apparent molecular mass of $80 \mathrm{MDa}$. This cryptic plasmid has not been mapped, but it could be similar in size and distribution to the $85 \mathrm{MDa}$ plasmid (pCH1) reported by Mintz et al. (1992). This also demonstrates that pLPG36 belongs to a different incompatibility group to that of the $80 \mathrm{MDa}$ cryptic plasmid, and confirms the results of Mintz et al. (1992) who found different incompatibility groups among L. pneumophila serogroup-1 plasmids.

Tully (1991) has shown the existence of another conjugative $36 \mathrm{MDa}$ plasmid with a conjugative frequency higher than that of $\mathrm{pCH} 1$ and higher than the mobilization frequency of pLPG36. Despite having found two different types of $36 \mathrm{MDa}$ plasmids (López de Felipe \& Martinez-Suárez, 1991), it was not possible to compare pLPG36, or another reported type of $36 \mathrm{MDa}$ Legionella plasmid, with the plasmid described by Tully (1991), since no restriction pattern was given to this plasmid. Because of this, and the fact that no-one else has demonstrated the existence of two 36 MDa plasmids in a single strain, there is no reason to suppose that pLPG36 can be mobilized by the conjugative plasmid reported by Tully (1991). This latter plasmid could, however, provide the necessary trans-acting functions to transfer a compatible, non-self-transmissible plasmid coresiding in the same donor cell.

The identification of the mobilization function in a cloned region of pLPG 36 could probably explain its wide distribution that we have reported previously (López de Felipe \& Martinez-Suárez, 1991) and suggests that there 
may be mobilizing plasmids in L. pneumophila capable of mediating DNA plasmid transfer between bacteria. The ability of Legionella plasmids to transfer may play a role in the spread of antibiotic resistance or any other selective advantage conferred by plasmids to this microorganism. The conjugative $36 \mathrm{MDa}$ plasmid of $L$. pneumophila reported by Tully (1991) has been demonstrated to confer ultraviolet light resistance to the strain in which it resides.

Nevertheless, the identification of an oriT gene function in pLPG36, which has the potential of replicating in $L$. pneumophila, should facilitate the construction of vectors consisting exclusively of Legionella DNA. This should provide a broadly applicable means of transferring plasmids between Legionella strains, thus facilitating the genetic manipulation of non-transformable strains.

\section{References}

EDELSTEIN, P. H. (1981). Improved semiselective medium for isolation of Legionella pneumophila from contaminated clinical and environmental specimens. Journal of Clinical Microbiology 14, 298-303.

Edelstein, P. H., Nakahama, C., Tobin, J. O., Calarco, K., Beer, K. B., Joly, J. R. \& Selander, R. K. (1986). Paleoepidemiologic investigation of Legionnaires' disease at Wadsworth Veterans Administration Hospital by using three typing methods for comparison of legionellae from clinical and environmental sources. Journal of Clinical Microbiology 23, 1121-1126.

Guiney, D. G. \& YaKobson, E. (1983). Location and nucleotide sequence of the transfer origin of the broad host range plasmid RK2. Proceedings of the National Academy of Sciences of the United States of America 80, 3595-3598.
Hanahan, D. (1983). Studies on transformation of Escherichia coli with plasmids. Journal of Molecular Biology 166, 557-580.

LóPez de Felipe, F. \& Martinez-Suárez, J. V. (1991). Wide distribution of a $36 \mathrm{MDal}$ plasmid among clinical and environmental Spanish isolates of Legionella pneumophila serogroup-1. Current Microbiology 23, 233-236.

Maher, W. E., Para, M. F. \& Plouffe, S. F. (1987). Subtyping of Legionella pneumophila serogroup-1 isolates by monoclonal antibody and plasmid techniques. Journal of Clinical Microbiology 25, 2281-2284.

Maniatis, T., Fritsch, E. F. \& Sambrook, J. (1982). Molecular Cloning: a Laboratory Manual. Cold Spring Harbor, NY: Cold Spring Harbor Laboratory.

Martinez, E., Bartolome, B. \& De la CruZ, F. (1988). pACYC 184derived cloning vectors containing the multiple cloning site and lacZ $\alpha$ reporter gene of $\mathrm{pUC} 8 / 9$ and $\mathrm{pUC18} / 19$ plasmids. Gene $\mathbf{6 8}$, $159-162$.

Mintz, C. S., FieldS, B. S. \& Zou, C.-H. (1992). Isolation and characterization of a conjugative plasmid from Legionella pneumophila. Journal of General Microbiology 138, 1379-1386.

Rosenberg, C., Casse-Delbart, F., Dusha, I., David, M. \& Boucher, C. (1982). Megaplasmids in the plant-associated bacteria Rhizobium meliloti and Pseudomonas solanacearum. Journal of Bacteriology $\mathbf{1 5 0}$, 402-406.

SHAPIRO, J. A. (1977). Bacterial plasmids. In DNA Insertions Elements, Plasmids and Episomes, pp. 601-704. Edited by A. I. Bukhari, J. A. Shapiro \& S. L. Adhya. Cold Spring Harbor, NY: Cold Spring Harbor Laboratory.

Stout, J. E., Joly, J., Para, M., Plouffe, J., Ciesielski, C., Blaser, M. J. \& YU, V. L. (1988). Comparison of molecular methods for subtyping patients and epidemiological linked environmental isolates of Legionella pneumophila. Journal of Infectious Diseases 157 486-495.

TulLy, M. (1991). A plasmid from a virulent strain of Legionella pneumophila confers resistance to ultraviolet light. FEMS Microbiology Letters $90,43-48$.

VIEIRA, J. \& MEssing, J. (1982). The pUC plasmids, a M13mp7 derived system for insertion mutagenesis and sequencing with synthetic universal primers. Gene 19, 103-109.

Willets, N. \& Wilkins, B. (1984). Processing of plasmid DNA during bacterial conjugation. Microbiological Reviews 48, 24-41. 